\title{
DELINEATING COMPARATIVE STUDIES ON BIOGAS PRODUCTION FROM CAMEL, DONKEY AND HORSE DUNGS
}

\author{
Buhari Samaila*, M.N Yahaya and Nasiru Abubakar \\ Department of physics with electronics Federal University Birnin Kebbi, P.M.B. 1157, Kebbi \\ State, Nigeria.
}

*Corresponding Author Email: kawara002@gmail.com

Cite this article:

Buhari S., M.N Yahaya, Nasiru A. (2021), Delineating Comparative Studies on Biogas Production from Camel, Donkey and Horse Dungs. Advanced Journal of Science, Technology and Engineering 1(1), 1-8. DOI: 10.52589/AJSTE-

TLYSUDBB.

\section{Manuscript History}

Received: 10 May 2021

Accepted: 27 May 2021

Published: 7 June 2021

Copyright $($ ) 2020 The Author(s). This is an Open Access article distributed under the terms of Creative Commons AttributionNonCommercial-NoDerivatives 4.0 International (CC BY-NC-ND 4.0 ), which permits anyone to share, use, reproduce and redistribute in any medium, provided the original author and source are credited.
ABSTRACT: The cost and the health effects of using other forms of energy, such as energy from fossil fuels and coal, make it necessary to find alternative sources of energy which are cheap and have no health effects on humans, animals and the environment. The energy derived from animal wastes, such as camel, donkey and horse dung, provide that alternative source of energy to humanity. To treat the problem of fossil fuel usage and greenhouse gas emissions, biogas is considered a potential source of clean renewable energy. The aim of this work is to compare the amount of biogas produced from cow, horse and camel dung. This work used three 1 litre capacity plastic gallons as prototype biodigesters. These biodigesters were operated and daily gas produced from the dung was observed for 37 days retention time. The digesters were fed with the same proportion of dung from each animal, and water. The operating temperatures of the digesters were maintained within the range of $34-39^{\circ} \mathrm{C}$, while $\mathrm{pH}$ values of the slurries ranged from 4.90 to 7.3. The biogas produced in 37 days retention time were found to be 14550 $\left.\mathrm{cm}^{3}\right) / 150 \mathrm{~g}$ for camels, $\left(2210 \mathrm{~cm}^{3}\right) / 150 \mathrm{~g}$ for donkeys and $(4000$ $\left.\mathrm{cm}^{3}\right) / 150 \mathrm{~g}$ for horses. It was observed that the dungs were stagnant for one week, and the more the retention time, the more gas was produced. This investigation revealed that the gas production process was started on day 7 , due to the fact that those animals were fed with fibrous materials and a longer time is required for digesting fibrous materials by microorganisms. The results obtained are compared in order of camel > horse > donkey. It was found that camels produce the highest volume of gas followed by horse and then donkey. The process of methane gas production, if extended to the commercial scale, would not only provide an alternative source of energy but would also be a means of environmental sanitation for the study area and Nigeria at large.

KEYWORDS: Biogas, Digester, Camel, Donkey, Horse dung. 


\section{INTRODUCTION}

The energy derived from animal dung has no adverse effects on the environment. Truly, energy produced from these materials (wastes) is extremely important and has a low cost of production. Delightfully, an individual can be able to digest his own waste food to get important farm supplements. Thus, this is not providing a way to harness the energy contents of the waste. The technology today used in biogas production is delightfully a two-way technology at this time. The gas produced can be of great importance to the satisfaction of humanity, while its leftovers can be transformed into fertilizer. This gas is a form of energy obtained from the digestion of animal and plant waste, which comprises methane, carbon dioxide and other impurities such as hydrogen, hydrogen sulfide and some nitrogen (Deressaa et al., 2015). The biogas is said to be a mixture of colorless and flammable gases obtainable by the process called anaerobic digestion of plant and animal waste. It typically comprises 50-70\% methane, 30-40\% carbon dioxide and other trace impurities of gases. It is widely confirmed that gas utilization of a country is a peak of its improvement and good living. The need for biogas in the sector of transportation and the generation of power are in increased demand in many countries of the world, including our country Nigeria (Onwuliri et al., 2013). At this time, the sources of energy required for electricity generation, heating and vehicle fuel are biogas, biofuels, solar energy, water energy, wind energy and geothermal energy. These sources are permanently renewed by natural processes or anthropogenic activity (Miroslav et al., 2009). Therefore, they appear to be effective solutions to the menaces resulting from the use of biofuels (Ozor et al., 2014).

Due to population growth and industrial development, world energy consumption considerably increased in the last decades. The use of fossil fuels is still the main energy source. However, fossil fuels are not renewable sources of energy. Furthermore, they are highly polluting, and their production tends to decrease during the next few decades. The increased energy consumption based on fossil fuels affects our environment through the greater amounts of greenhouse gas emissions, the environmental pollution of water, air and soil, and the climate changes, which dramatically influence the quality of life and the health of people. Therefore, it is important to develop new sustainable energy supply systems that cover the increasing energy demand for renewable sources. Reducing greenhouse gas emissions through renewable energy production is of rising importance (Moutaz et al., 2019).

As at 2007, it was reported that animal and agricultural wastes in Nigeria stood at 0.781 and 0.256 million tons per day respectively (Onaji et al., 2019). Vindis et al. (2009) reported that from animal waste alone, Nigeria can generate 4.75 x 109 MJ per annum. Ugwuh (2009) reported that an average Nigerian generates about $0.48 \mathrm{~kg}$ of municipal solid waste daily. Ovueni et al. (2010) also predicted that the municipal solid waste generation in Nigeria will reach 58 million tons daily by 2050. In spite of this great benefit in energy generation, Nigeria has not been able to harness this alternative source of energy adequately (Onaji et al., 2019).

\section{Theoretical Background}

The need of energy in the world is on an increased demand in which the sources are utilized. Biogas, as a renewable energy source, assists us in conserving biofuels. The benefits of biogas can be extended to villages under favorable conditions through a good preparation of community biogas plants. These technological benefits of biogas are not applied for lightning and cooking only, but also serve as farm supplements for the nation's farmers. The study comes up with the aims of transforming animal waste into biogas. It is remarkable for undeveloped 
countries to use this technology in order to obtain their energy requirement, which will continue endlessly in the coming years (Neeha \& Shafqat, 2012).

The methane gas produced in some parts of the world can replace biofuels and oils which had negative impacts on the living areas and in the same vein, aggravated the living standard of the dwellers. The biogas has many uses but its technology does not wholly capture the problems within it; the frequent ones: it requires a long period of time to digest the compost materials, usually 30-50 days and in the winter period, less gas is produced. These problems need to be eliminated so as to make this technology known in the villages. The scholar makes use of different methods to improve methane gas production across the globe (Vijay et al., 2013).

The utilization of energy is on an increase and in those days brought about fear of finishing the world's reserve of hydrocarbon and other forms of energy in the coming days. The large usage of fossil fuels leads to untold damage to the populations in various forms. About $90 \%$ of the energy utilization is due to fossil fuels. Due to modernization of our industries and increase in population, our economy and technologies are greatly dependent on natural resources that can be renewed. These sources are less costly, so they can dominate the use of fossil fuels easily. By increasing the biogas production, the following can be prevented: air pollution, soil pollution and water pollution. Hence, the economy of the nations or the world at large will rapidly grow, due to natural sources available in the environment (Nada \& Alrikabi, 2014).

The study was conducted to analyze the total dung of animal-based biogas potential to attain the increasing power demand of the population. The study investigated that the Bathinda district encompasses an animal population of 423375 and animal dung energy produced is 1385247 GJ per year. Their results have shown that electrical energy derived from an extra animal's dung with efficiency $35 \%$ is $384.8 \mathrm{GWH}$ per year. The greenhouse gas emission is also reduced by the use of this dung (Gagandeep et al., 2014).

The donkey waste was used to produce biogas using a digester. The collected samples were investigated and analyzed. This methane gas produced was investigated with the assistance of gas analyzer. The results of biogas produced indicated that the methane contents account for about $55 \%$ without co-digesting it with other wastes. Finally, the results of the investigation indicated that the wastes of donkeys are important materials for the production of methane gas (Mukumba et al., 2016).

The biogas produced undergoes several stages - four different stages. The first stage involves the transformation of animal dung into simple sugar and it is called hydrolysis. The second stage involves the transformation of simple sugar into propanoic acid and methanol acid, and it is called acidogenesis. Third stage has to do with the breaking down of propanoic acid and methanol into hydrogen, carbon dioxide and acetic acid; this process is called acetogenesis. The fourth stage involves the transformation of hydrogen and acetic acid to methane gas and carbon dioxide with the help of bacteria called methanogens; the whole process is known as methanogenesis. The production of methane gas and carbon dioxide leads to the attainment of animal dung balance. The biogas extracted from this dung consists of methane and carbon dioxide together with traces of gases. It is a better burning agent than coals and releases very little carbon dioxide per unit of energy (Calverton, 2008). 


\section{METHODOLOGY}

\section{Sample collection}

The study area of this research is Kawara Manu, Maiyama L.G Kebbi State, Nigeria. The dungs were obtained from three different areas of Kawara. The samples were collected in polyethylene bags and labeled as Camel, Donkey and Horse for easy identification, and then transported immediately to the laboratory for use by the manual removal of unwanted particles like stones, woods and other non-biodegradable materials (Kamen et al., 2018). The samples thus collected were sun-dried for over a period of 10 days and ground using wooden pestle and mortar. Sieve ( $2 \mathrm{~mm}$ size) was used in order to obtain powdered samples which were stored in separate black polythene bags (Onaji et al., 2019). The sample powder weighed 150g for each animal dung. A $1 \mathrm{~L}$ capacity gallon was made to be the digester in this research, and the tubes were used as gas collectors.

\section{Preparation of Slurry and digestion}

From the prepared samples, 150g each of Camel, Donkey and Horse dung was weighed and mixed with $800 \mathrm{~cm}^{3}$ of water in a beaker to obtain slurries of 1:4 substrates:water ratio. The slurry prepared was stirred and allowed to equilibrate for over 24 hours. The digesters were sealed with an adhesive to prevent leakages and connected with delivery pipes which conveyed the gas from the digester to the gas collectors (tube). The digesters were firmly closed to attain anaerobic conditions and allowed in this state for a period of 37 days. The amount of gas produced was monitored at daily intervals. The experiment was conducted under mesophilic temperature range of $37-40^{\circ} \mathrm{C}$ (Onaji et al., 2019) and $\mathrm{pH}$ of 4.9-7.3.

The stages which biogas undergoes during the process can be presented in a flow chart as shown below:
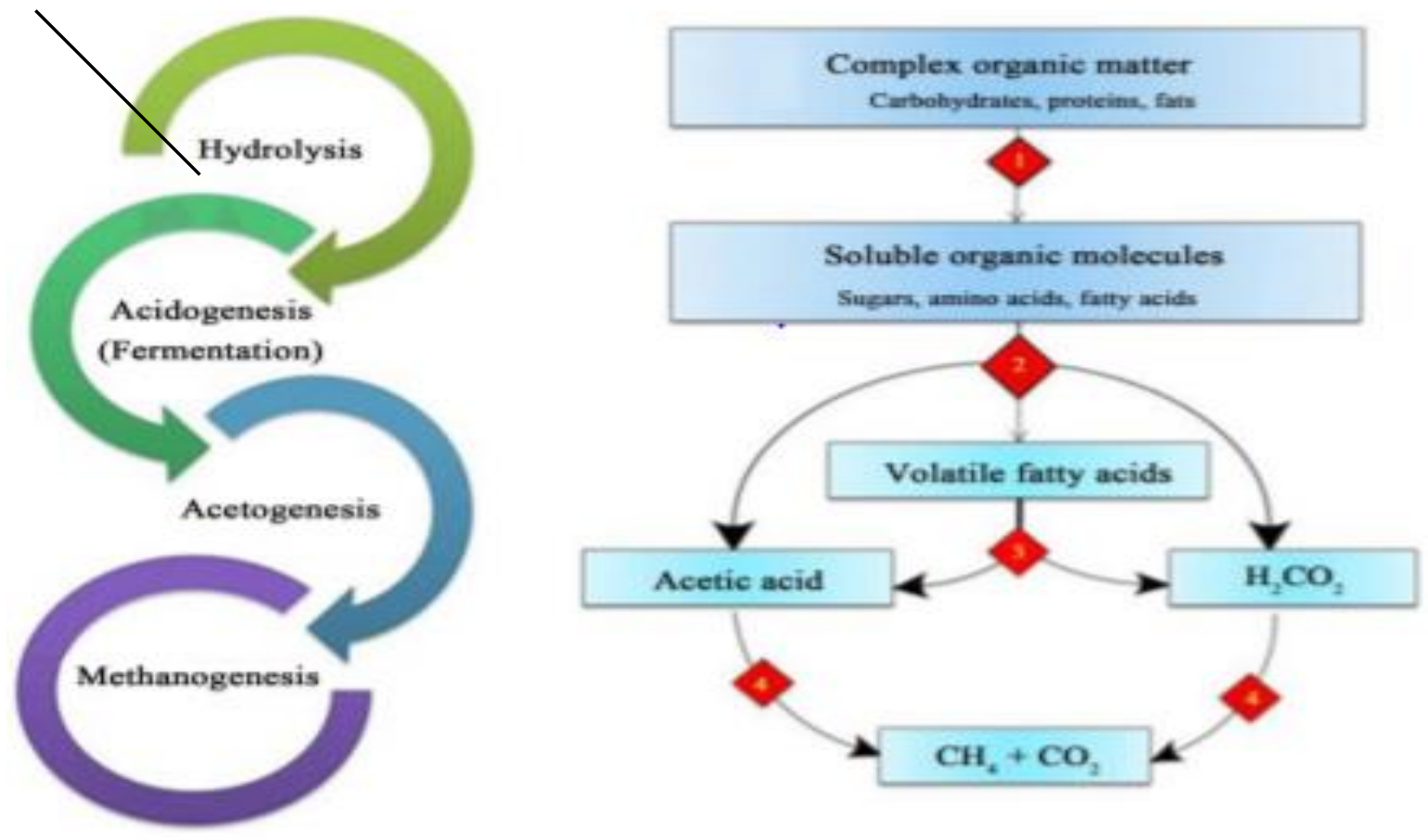

Figure 1: Flow Chart of Anaerobic Digestion Process (Moutaz et al., 2019). 
The rate of biogas production depends greatly on the temperature of the digesters. Anaerobic digestion process generally occurs at three temperature ranges. These ranges are defined as psychrophilic $\left(15^{\circ} \mathrm{C}-20^{\circ} \mathrm{C}\right)$, mesophilic $\left(30^{\circ} \mathrm{C}-40^{\circ} \mathrm{C}\right)$ and thermophilic $\left(50^{\circ} \mathrm{C}-60^{\circ} \mathrm{C}\right)($ Moutaz et al., 2019). The total gas produced for each animal dung was calculated using the expression below:

The total gas produced in 37 days $=\sum \quad X_{N}$ (1)

where $N=1,2,3,4$, representing the number of days. For each day, the volume of gas produced was recorded, up to the period of 37 days, as shown in the equation 1 above. The total volumes of gas produced from each digester were tabulated.

\section{RESULTS AND DISCUSSION}

\section{Results}

The cumulative results of Biogas production from Camel, Donkey and Horse dung are shown in table 1 below; the production was delayed till day 7 . The $\mathrm{pH}$ for the dung fluctuated from the first day to the tenth day, between 4.9 and 7.3, after which it began to decrease gradually for the remaining days of the retention period. As it was observed in the first few days, the $\mathrm{pH}$ of dung decreased due to high volatile fatty acid. The gradual reduction explains the gradual change of stage of the production of biogas, from hydrolysis to acidogenesis, in which the slurry becomes acidic and forms substrates, after which it produces biogas (as shown in figure 1). The readings were taken every 24 hours; the percentage of biogas production in 37 days retention time is shown in Figure 2.

Table 1: Total biogas produced in five weeks two days ( 37 days)

\begin{tabular}{|l|l|}
\hline SLURRY (mixture of dung and water) & Total Volume of gas produced $\left(\mathrm{cm}^{3}\right)$ \\
\hline CAMEL & 4550 \\
\hline DONKEY & 2210 \\
\hline HORSE & 4000 \\
\hline $\begin{array}{l}\text { Total gas produced from camel, donkey and } \\
\text { horse }\end{array}$ & $4550+2210+4000=10760 \mathrm{~cm}^{3}$ \\
\hline
\end{tabular}

The percentage of the volume of biogas produced from the three samples were calculated using the expression below:

Percentage of gas produced by camel dungs $=\frac{4550}{10760} \times 100=42.290 \%$

Percentage of gas produced by donkey dungs $=\frac{2210}{10760} \times 100=20.540 \%$

Percentage of gas produced by horse dungs $=\frac{4000}{10760} \times 100=37.175 \%$ 


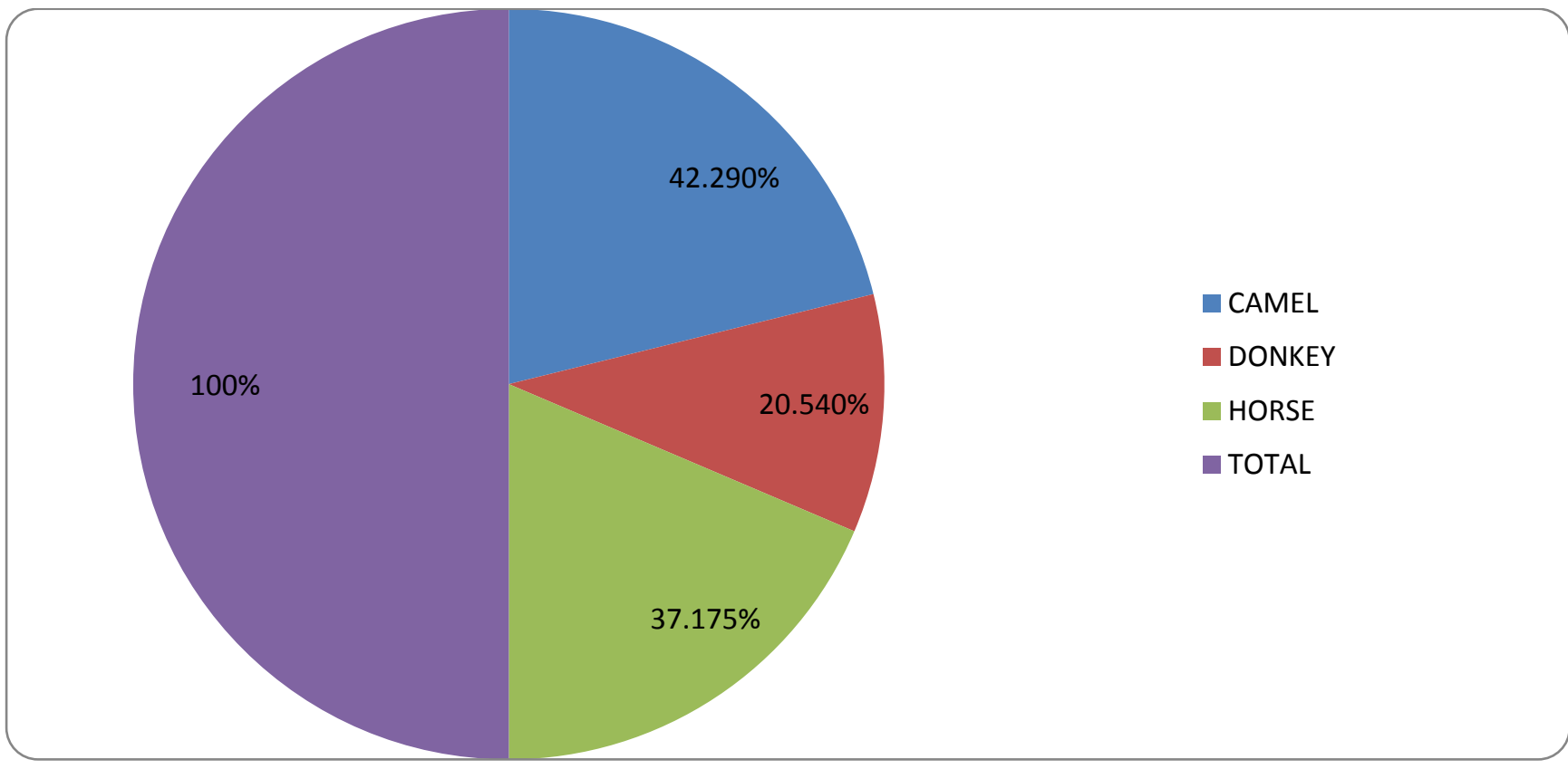

Figure 2: Pie chart showing the percentage of total biogas produced from three samples in 37 days.

\section{Discussion}

Table 1 shows that in all the three dungs, most of the biogas productions occurred in the second week. This can also be traced to the fact that most of them feed on fibrous materials and microorganisms require a longer time to degrade fibrous materials. In the cumulative production of biogas from the three dungs for 37 days shown in table 1, the Camel dung had the highest yield of $4550 \mathrm{~cm} 3 / 150 \mathrm{~g}$ dry dung, followed by the Horse dung having $4000 \mathrm{~cm} 3 / 150 \mathrm{~g}$ dry dung, and Donkey dung with $2210 \mathrm{~cm} 3 / 150 \mathrm{~g}$ dry dung. The total volume of gas from the three samples is equal to $10760 \mathrm{~cm}^{3}$. Biogas production virtually stopped after the 37 th day for the three samples.

In figure 2 , the pie chart shows the percentage of the total gas produced by each of the dung collected from the study area. It was observed that Camel has the largest percentage of $42.290 \%$ while Donkey has the least percentage.

\section{CONCLUSION}

The results of the biogas productions from Camel, Donkey and Horse dung showed that an appreciable quantity of biogas can be obtained from the dung of these three domestic animals, which if explored in large scale, will be of great economic benefit and help to combat environmental pollution. The investigation also revealed that camels' dung has greater potential to produce methane gas compared to other dung (horse \& donkey), and its usage should be recommended due to its high production yield. The animals' dung are always available in the study area and can be used as sources of fuel if managed properly. 


\section{REFERENCE}

Claverton E.C, (2008). "Biomethane fueled vehicles, the carbon neutral option" claverton Energy conference, Bath, UK, October $24^{\text {th }} 2008$

Deressa L, Solomon L, Chavan R.B, Daniel M, Anbessa D (2015) "Production of Biogas from Fruit and Vegetable Wastes Mixed with Different Wastes" Environment and Ecology Research 3(3): 65-71, http://www.hrpub.org, DOI: 10.13189/eer.2015.030303

Gagandeep Kaur, Yadwinder Singh Brar, D.P.Kothari (2014) "Estimation of Large Animals Dung for Power Generation - A Case Study of District Bathinda, Punjab", IOSR Journal of Electrical and Electronics engineering (IOSR-JEEE) e-ISSN: 2278-1676,pISSN: 2320-3331, Volume 9, Issue 5 Ver. III , PP 50-55, www.iosrjournals.org

Kamen, F. L; Nnamchi, S.N; Ike, I.S, Orga, A.C. and Nkwocha. A.C.(2018) "Comparative Study Of The Production Of Biogas From Cow, Pig And Poultry Dung" Journal of Multidisciplinary Engineering Science and Technology (JMEST), ISSN: 2458-9403, Vol. 5 Issue 10.

Miroslav Hutňan, Igor Bodík, Andrea Blšt'áková (2009)“Production of biogas from renewable energy sources" 36th International Conference of SSCHE, May 25-29, Tatranske Matliare, Slovakia. ISBN 978-80-227-3072-3

Moutaz B, Tarek H and Yousif H (2019) "Experimental Study of Biogas Production from Cow Dung as an Alternative for Fossil Fuels" Journal of Sustainable Bioenergy Systems, 9, 91-97, http://www.scirp.org/journal/jsbs, ISSN Online: 2165-4018

Mukumba P, Makaka G, Mamphweli S (2016) "Anaerobic digestion of donkey dung for biogas production". S Afr J Sci.; 112(9/10), Art.2016-0013, 4pages Nada Kh. M. A. Alrikabi (2014) "Renewable Energy Types" Journal of Clean Energy Technologies, Vol. 2, No. 1,

Neeha F and Shafqat H (2012) "Effective Use of Technology to Convert Waste into Renewable Energy Source" life science, pp (654-661), (ISSN: 1097-8135).

Onaji, I.A, Asiru, R.A2 and Eluma, M (2019) "Effect of pH on the Rate of Biogas Production using Cow dung and Rice husk" Journal of Academia and Industrial Research (JAIR), Volume 7, Issue 8

Onwuliri F.C, Onyimba IA and Nwaukwu IA (2013) "Generation of Biogas from Cow Dung" Journal of Bioremediation \& Biodegradation

Ovueni, U.J., Sadoh, Y.O., Okorejior, E.A. and Alebu, O. (2010) "Population growth rate and waste management challenges in a developing economy" Int. J. Hospitality Leisure Tourism. 2(1): 231-242.

Ozor O.c, Agah M.V, Ogbu K.I, Nnachi A.U, Udu-ibiam O.E, Agwu M.M (2014) "Biogas Production Using Cow Dung from Abakaliki Abattoir in South-Eastern Nigeria" International journal of scientific and technology research volume 3, issue 10.

Ugwuh, U.S. (2009) "The state of solid waste management in Nigeria” Waste Management, 29:2787-2790

Vijay K, Sridevi V, Rani K, Sakunthala M and Santosh C. K (2013) "A review on production of biogas, fundamentals, applications \& its recent enhancing techniques", K.Vijay Kumar et al./ Elixir Chem. Engg. 57, 14073-14079, Available online at www.elixirpublishers.com (Elixir International Journal)

Vindis, P., Mursec, B., Janzekovic, M. and Cus, F. (2009) "The impact of mesophilic and thermophilic anaerobic digestion on biogas production" J. Achievements Mat.Manufact Engg. 38(2): 192-198. 